Stanisław Wieteska*

\title{
UBEZPIECZENIA OD KRADZIEŻY RUCHOMYCH ZABYTKÓW KULTURY Z EKSPOZYCJI STALEJ W POLSCE
}

\section{Postawienie problemu}

Polska posiada wiele dóbr zabytkowych ruchomych, nieruchomych, archeologicznych, które wymagają ochrony i zabiegów konserwatorskich.

Pod pojęciem ekspozycji stałej będziemy rozumieć ruchome zabytki kultury znajdujące się w obiektach sakralnych, muzeach, prywatnych kolekcjach, instytucjach publicznych, zamkach i pałacach, które można w każdej chwili zdemontować, przenieść, przewieźć.

Podstawowym aktem prawnym dotyczącym ochrony i opieki nad zabytkami jest ustawa z 23 lipca 2003 r. (Dz. U. 2003, nr 162, poz. 1568). Akt ten określa: formy i sposoby ochrony zabytków, zagospodarowanie, badanie, prace konserwatorskie, nadzór konserwatorski, zasady wywozu zabytków za granicę, restytucję zabytków niezgodnie $\mathrm{z}$ prawem $\mathrm{z}$ terytorium państwa członkowskiego, zasady finansowania opieki nad zabytkami, krajowy program ochrony zabytków i opieki nad zabytkami w wypadku konfliktu zbrojnego oraz sytuacji kryzysowych, organizację organów ochrony zabytków, przepisy karne.

Ubezpieczenie zabytków kultury jest obszarem mało rozpoznanym od strony rynku ubezpieczeniowego. W literaturze przedmiotu spotykamy się sporadycznie z publikacjami poświęconymi ubezpieczeniom różnych dzieł sztuki ${ }^{1}$.

Celem artykułu jest przedstawienie skali kradzieży ruchomych zabytków kultury w Polsce, a następnie wskazanie warunków objęcia tych dóbr ochroną ubezpieczeniową.

$\mathrm{W}$ artykule postawiono tezę, że objęcie ochroną ubezpieczeniową dziedzictwa narodowego jest możliwe.

* Uniwersytet Łódzki, Wydział Ekonomiczno-Socjologiczny.

1 Zob. J. Bowring, Ubezpieczenie dzieł sztuki - uwagi ogólne, w: Rynek sztuki. Aspekty prawne, red. W. Kowalski, K. Zalasińska, Wolters Kluwer Polska, Warszawa 2011, s. 248-259. 
Jako metodę badawczą przyjęto analizę dostępnych danych statystycznych dotyczących kradzieży dzieł sztuki.

Autor pragnie zwrócić uwagę zakładom ubezpieczeń majątkowo-osobowych i na ten obszar ryzyka.

\section{Pojęcia podstawowe}

Zgodnie z art. 3 ust. 1 Ustawy z 23 lipca 2003 r. przez zabytek rozumie się - „nieruchomość lub rzecz ruchomą, ich części lub zespoły, będące dziełem człowieka lub związane z jego działalnością i stanowiące świadectwo minionej epoki bądź zdarzenia, których zachowanie leży w interesie społecznym ze względu na posiadaną wartość historyczną, artystyczną lub naukową".

Z tej definicji weźmiemy pod uwagę jedynie zabytki ruchome - przez zabytek „ruchomy rozumiemy rzecz ruchomą jej część lub zespół rzeczy ruchomych”. Do tej definicji dodajmy, że za zabytek ruchomy będziemy uważać rzecz, którą można przenieść, przewieźć bez lub z jej demontażem, rozbiórką i złożeniem² ${ }^{2}$ Zgodnie z art. 6 ust. 2 do zabytków ruchomych zaliczać będziemy:

- dzieła sztuk plastycznych, rzemiosła artystycznego i sztuki użytkowej,

- kolekcje stanowiące zbiory przedmiotów zgromadzonych i uporządkowanych według koncepcji osób, które tworzyły kolekcje,

- numizmaty oraz pamiątki historyczne, a zwłaszcza militaria, sztandary, pieczęcie, odznaki, medale i ordery,

- wytwory techniki, a zwłaszcza urządzenia środków transportu oraz maszyny i narzędzia świadczące o kulturze materialnej, charakterystyczne dla dawnych i nowych form gospodarki, dokumentujące poziom nauki i rozwoju cywilizacyjnego,

- materiały biblioteczne w myśl art. 5 ustawy z dnia 27 czerwca 1997 r. o bibliotekach (Dz. U. 1998, nr 85, poz. 539; Dz. U. 2001, nr 106, poz. 668; Dz. U. 2002, nr 129, poz. 1440 oraz Dz. U. 2002, nr 113 poz. 984),

- instrumenty muzyczne,

- wytwory sztuki ludowej, rękodzieła oraz inne obiekty etnograficzne,

- przedmioty upamiętniające wydarzenia historyczne bądź działalność wybitnych osobistości lub instytucji.

2 W artykule traktujemy pojęcia zabytek, dobro jako synonimy. 
Zdaniem H. Urbańskiego jednym ze składników pojęcia dzieła sztuki powinna być fascynacja. Chęć zdobycia dzieła sztuki częstokroć graniczy z niepohamowaną namiętnością̧ .

Lista zabytków ruchomych jest bogata. Każdy z nich jest zarejestrowany i opisany w rejestrach zabytków prowadzonych przez wojewódzkiego konserwatora zabytków. Wpisu zabytku ruchomego dokonuje się na podstawie decyzji wydanej przez wojewódzkiego konserwatora zabytków na wniosek właściciela. Rejestr zabytków ruchomych jest okresowo aktualizowany.

Pod pojęciem ochrony zabytków rozumieć będziemy podejmowanie przez organy administracji publicznej czynności mających na celu zapobieganie zagrożeniom, które mogą spowodować uszczerbek dla wartości zabytku ruchomego, zapewnienie warunków prawnych, organizacyjnych i finansowych do ochrony, kontrolę stanu itp.

Do powyższego pojęcia należy dołożyć opiekę nad zabytkami sprawowaną przez ich właścicieli lub posiadaczy przy spełnieniu odpowiednich warunków.

Na szczególną uwagę zasługuje ochrona zabytków polegająca (art. 4, ust. 1 Ustawy) na przeciwdziałaniu kradzieży, zaginięciu lub nielegalnemu wywozowi zabytków za granicę. Pojecie kradzieży rozszerzymy o kradzież z włamaniem, gdyż w bardzo wielu wypadkach mamy do czynienia $\mathrm{z}$ tego rodzaju zdarzeniem.

Szczególną uwagę należy zwrócić na działania podejmowane w zakresie ochrony zabytków sztuki sakralnej ${ }^{4}$ Zalecenia Soboru Watykańskiego i dokumentów posoborowych oraz Papieskiej Komisji ds. Kościelnych Dóbr Kultury są realizowane przez Episkopat Polski. Świadczą o tym m.in. instrukcja o ochronie zabytków i kierunkach rozwoju sztuki kościelnej z 16 kwietnia 1966 r., a także kilka konferencji poświęconych zabezpieczeniu sakralnych dzieł sztuki przed kradzieżą, dewastacją, sprzedażą. Mocny akcent położony został na powszechną inwentaryzację wszystkich sakralnych dzieł sztuki.

\section{Kradzież ruchomych zabytków w Polsce - skala problemu}

Pomimo wielu lat doświadczeń w zakresie ochrony dziedzictwa kulturowego nie mamy rzetelnych danych o wszystkich formach przestępczości przeciwko zabytkom. Brakuje również rzetelnej struktury rodzajowej i przestrzennej skali kradzieży dzieł

3 E. Geppert, Z zagadnień ubezpieczeń dziet sztuki, „Wiadomości Ubezpieczeniowe” 1975, nr 11, s. 13.

4 Więcej na ten temat: M. Leszczyński, Ochrona zabytków sztuki sakralnej w świetle aktualnego prawa Kościoła katolickiego, „Muzealnictwo” 2008, nr 49, s. 79-87. 
sztuki ${ }^{5}$. Nie posiadamy również rzetelnej bazy danych o zaginionych ruchomych zabytkach, co uniemożliwia porównanie skali zjawiska w poszczególnych latach Główny ciężar walki z przestępczością w zakresie zabytków ruchomych spada na Policję, Straż Graniczną oraz Służby Celne.

Kradzież dzieł sztuki w niektórych wypadkach wiąże się z próbą wymuszenia okupu. Często osoby poszkodowane nie zgłaszają świadomie strat, które poniosły. Skalę kradzieży dzieł sztuki - określoną na podstawie ststystyk policyjnych - przedstawia rysunek 1 .

\section{Rysunek 1. Liczba zdarzeń kradzieży dóbr kultury i zabytków w latach 2000-2009}

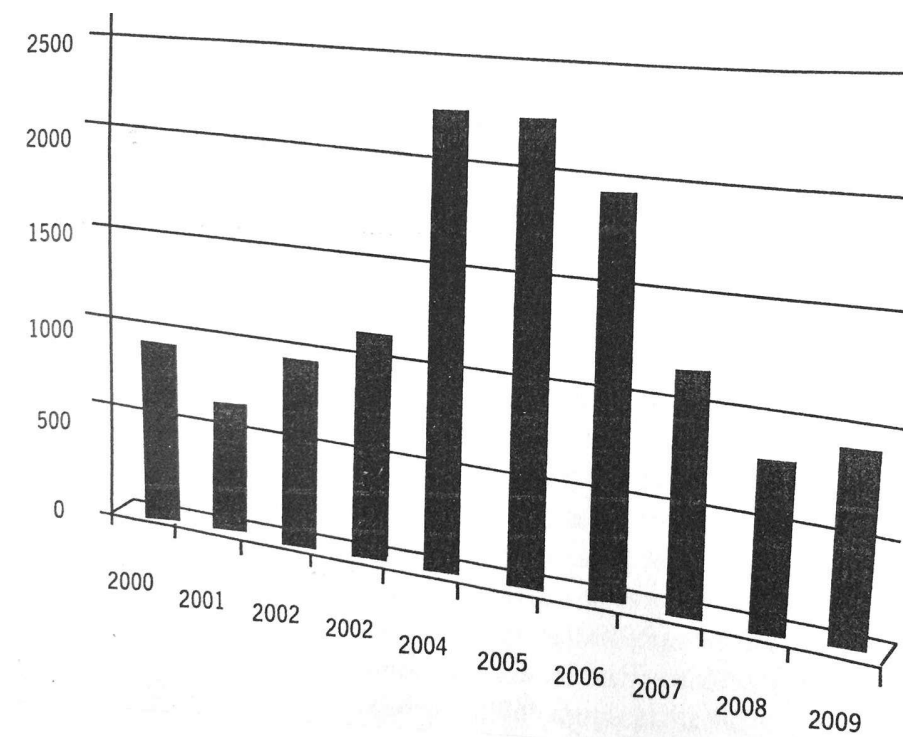

Źródło: P. Ogrodzki, Przestępczość przeciwko zabytkom. Krótka charakterystyka problemu. Stan na 2010 r., „Cenne, Bezcenne, Utracone”, Ośrodek Ochrony Zbiorów Publicznych, Warszawa 2010, s. 5.

Dane prezentowane na rysunku 1 pokazują, że najwięcej kradzieży dóbr kultury wystąpiło w latach 2004-2006.

Warto przypomnieć, że na mocy konwencji UNESCO z 1954 r. (uzupełnionej o konwencję z 1970 r.) kradzież dzieł sztuki nie podlega przedawnieniu, a prawa do tych dzieł mogą być rewindykowane niezależnie od upływu czasu6.

5 P. Ogrodzki, Przestępczość przeciwko zabytkom. Krótka charakterystyka problemu. Stan na 2010 r., „Cenne, Bezcenne, Utracone”, Ośrodek Ochrony Zbiorów Publicznych, Warszawa 2010, s. 3-5.

6 M. Korzeniowska-Marciniak, Gdzie szukać skradzionych dzieł sztuki, „Gazeta Antykwaryczna” 2002, nr 6, s. 42. 
Należy odnotować aktywność Polaków mieszkających za granicą, śledzących aukcje prywatnych kolekcji w celu odzyskania skradzionych w Polsce dzieł sztuki ${ }^{7}$.

Między innymi na zlecenie zachodnich firm ubezpieczeniowych prowadzone są rejestry skradzionych dzieł (Art Losses Register i Invaluable). Zadaniem tych firm jest ustalenie pochodzenia dzieł sztuki na aukcjach, a także weryfikowanie katalogów aukcyjnych ${ }^{8}$.

Jak dowodzi praktyka, ruchome obiekty zabytkowe zlokalizowane są praktycznie na terenie całej Polski. Zdecydowana większość znajduje się w rękach prywatnych, muzeach, galeriach.

Kradzieże w muzeach stanowią tylko fragment przestępczości przeciwko zabytkom ruchomym w Polsce. Skalę zjawiska kradzieży w muzeach przedstawia rysunek 2.

Rysunek 2. Liczba kradzieży dóbr kultury i zabytków w muzeach w latach 1989-2005

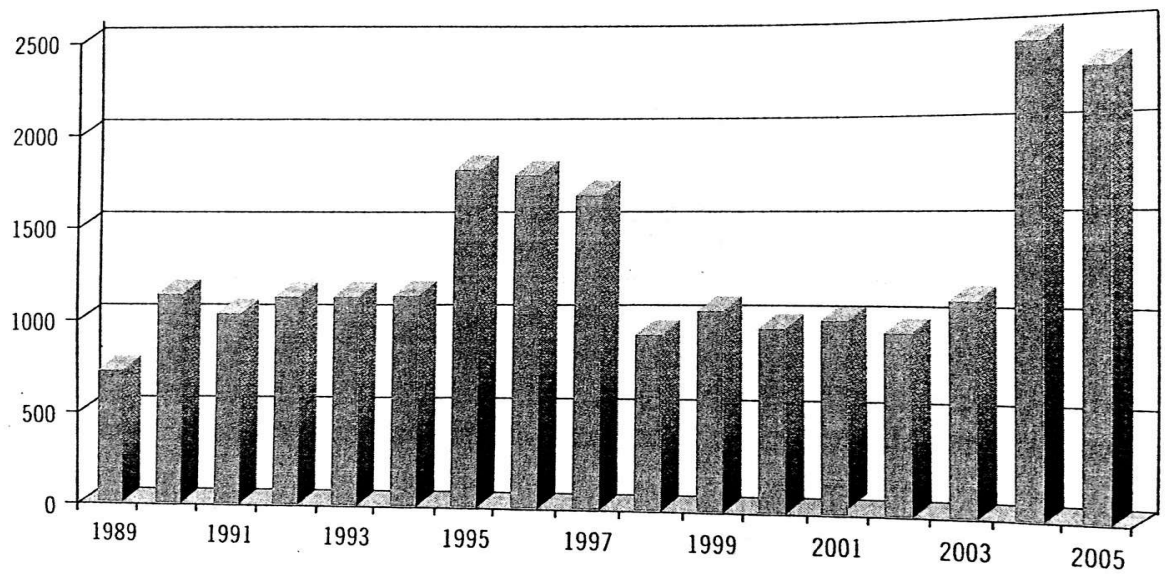

Źródło: P. Ogrodzki, Przestępczość w polskich muzeach, „Cenne, Bezcenne, Utracone” 2006, nr 4(49), Ośrodek Ochrony Zbiorów Publicznych, s. 25.

Najwięcej kradzieży zanotowano w latach 1995-1997 i 2004-2005. Na kradzieże dzieł sztuki narażeni są prywatni kolekcjonerzy. Skalę problemu przedstawia tabela 1.

Z danych zawartych w tabeli 1 wynika, że w latach $2007-2011$ ok. $85 \%$ przestępstw było dokonanych w budynkach samodzielnych i wielorodzinnych, posiadających zabytki ruchome.

7 A. Krochmal, Ochrona polskiego dziedzictwa narodowego poza granicami kraju, „Cenne, Bezcenne, Utracone" 2006, nr 1, s. 37-38.

8 Ibidem, s. 43. 
Tabela 1. Przestępstwa (stwierdzone) przeciwko zabytkom, przy uwzględnieniu miejsca ich popełnienia w Polsce w latach 1998-2011

\begin{tabular}{|l|c|c|c|}
\hline \multirow{2}{*}{ Rok } & \multicolumn{3}{|c|}{ Miejsce popełnienia przestępstwa } \\
\cline { 2 - 4 } & $\begin{array}{c}\text { Budynek (samodzielny lub } \\
\text { wielorodzinny) }\end{array}$ & $\begin{array}{c}\text { Kościót, kaplica (obiekty } \\
\text { sakralne) }\end{array}$ & $\begin{array}{c}\text { Muzeum, } \\
\text { galeria }\end{array}$ \\
\hline $1998^{*}$ & 294 & 126 & 27 \\
\hline $1999^{*}$ & 295 & 129 & 35 \\
\hline $2000^{*}$ & 298 & 120 & 33 \\
\hline $2001^{\star *}$ & 259 & 77 & 31 \\
\hline $2002^{\star * *}$ & 244 & 165 & 25 \\
\hline $2004^{\star * * *}$ & 344 & 56 & 53 \\
\hline $2005^{\star * * * *}$ & 399 & 47 & 37 \\
\hline 2006 & 296 & 45 & 32 \\
\hline 2007 & 196 & 26 & 18 \\
\hline 2008 & 126 & 19 & 12 \\
\hline 2009 & 217 & 17 & 16 \\
\hline 2010 & 132 & 15 & 13 \\
\hline 2011 & 196 & 20 & 13 \\
\hline Razem & $\mathbf{8 6 7}$ & $\mathbf{9 0}$ & $\mathbf{7 2}$ \\
\hline
\end{tabular}

* Informacja dotycząca stanu zagrożenia przestępczością kryminalną skierowaną przeciwko dobrom kultury w 2000 r., „Cenne, Bezcenne, Utracone” 2001, nr 1, s. 12.

** Informacja nt. stanu zagrożenia przestęppczością przeciwko dobrom kultury w Polsce w latach 1999-2001, „Cenne, Bezcenne, Utracone” 2001, nr 1.

*** Informacja nt. stanu zagrożenia przestępczością przeciwko dobrom kultury w 2002 r., „Cenne, Bezcenne, Utracone, nr 1-2, s. 6.

**** Informacja nt. skali zagrożenia przestępczością kryminalną przeciwko zabytkom w latach 2004-2005, "Cenne, Bezcenne, Utracone" 2006, nr 1, s. 10-12.

«**** Informacja nt. skali zagrożenia przestępczością kryminalną przeciwko zabytkom w Polsce w latach 2005-2006, „Cenne, Bezcenne, Utracone” 2007, nr 1, s. 4-8.

Źródło: P. Ogrodzki, Zagrożone kolekcje, zagrożeni kolekcjonerzy, „Cenne, Bezcenne, Utracone” 2012, nr 2(71), s. 28.

Również ważny jest rozkład przestrzenny kradzieży. Częściowe dane w tym zakresie przedstawia tabela 2 .

Tabela 2. Przestrzenny rozkład kradzieży obiektów zabytkowych ruchomych w latach 2000-2006 (w liczbach zdarzeń)

\begin{tabular}{|c|c|c|c|c|c|c|c|c|c|c|c|c|}
\hline \multirow[b]{2}{*}{ Lp. } & \multirow[b]{2}{*}{ Województwa } & \multicolumn{2}{|c|}{$2000^{*}$} & \multicolumn{4}{|c|}{$2001^{\star *}$} & \multirow{2}{*}{\begin{tabular}{|l|}
2002 \\
Ogót.
\end{tabular}} & \multirow{2}{*}{$\frac{2003}{\text { Ogót. }}$} & \multirow{2}{*}{\begin{tabular}{|l|}
2004 \\
Ogót.
\end{tabular}} & \multirow{2}{*}{$\begin{array}{c}2005 \\
\text { Ogót. }\end{array}$} & \multirow{2}{*}{\begin{tabular}{|l|}
2006 \\
Ogót
\end{tabular}} \\
\hline & & $\begin{array}{l}\text { Mieszkania } \\
\text { prywatne }\end{array}$ & $\begin{array}{l}\text { Obiekty } \\
\text { sakralne }\end{array}$ & Mieszkania & $\begin{array}{l}\text { Obiekty } \\
\text { sakralne }\end{array}$ & Galerie & Inne & & & & & \\
\hline 1 & $\begin{array}{l}\text { mazowieckie } \\
\text { (z Warszawą) }\end{array}$ & 61 & 58 & 60 & 8 & 5 & 48 & 154 & 68 & 208 & 210 & 150 \\
\hline 2 & małopolskie & 54 & 23 & 51 & 31 & 2 & 49 & 46 & 78 & & & \\
\hline 3 & śląskie & 33 & 27 & 26 & 19 & 2 & 86 & 59 & t & 171 & 231 & 183 \\
\hline
\end{tabular}




\begin{tabular}{|r|l|r|r|r|r|r|r|r|r|r|r|r|}
\hline 4 & dolnośląskie & 24 & 17 & 18 & 25 & 5 & 61 & 106 & 100 & 159 & 169 & 161 \\
\hline 5 & lubuskie & 5 & 2 & 7 & 6 & - & 14 & & & & & \\
\hline 6 & podlaskie & 4 & 3 & & & & & & & & & \\
\hline 7 & świętokrzyskie & 2 & 5 & & & & & & & & & \\
\hline 8 & podkarpackie & 3 & 1 & 8 & 4 & - & 14 & & & & & \\
\hline 9 & opolskie & - & - & 5 & 8 & - & 6 & & & & & \\
\hline 10 & tódzkie & & & & & & & & & 859 & 641 & 445 \\
\hline 11 & pomorskie & & & & & & & & & 167 & 301 & 265 \\
\hline
\end{tabular}

* Informacja dotycząca stanu zagrożenia przestępczością kryminalną skierowaną przeciwko dobrom kultury w 2000 r., „Cenne, Bezcenne, Utracone” 2001, nr 1, s. 12.

** Informacja nt. stanu zagrożenia przestępczością przeciwko dobrom kultury w Polsce w latach 1999-2001, "Cenne, Bezcenne, Utracone" 2002, nr 1.

Źródło: Obliczenia własne na podstawie danych kwartalnika „Cenne, Bezcenne, Utracone” z lat 1998-2004.

Z danych zawartych w tabeli 2 wynika, że najwięcej kradzieży zanotowano w województwach: mazowieckim, śląskim, dolnośląskim, łódzkim i pomorskim. Równie ważna jest struktura rodzajowa skradzionych ruchomych dóbr kultury (tabela 3).

Tabela 3. Struktura rodzajowa skradzionych ruchomych dóbr kultury w Polsce w latach 1998-2004 (w szt.)

\begin{tabular}{|l|c|r|r|r|r|c|c|}
\hline Rodzaj zabytku ruchomego & $1998^{\star}$ & $1999^{\star}$ & $2000^{*}$ & $2^{2001^{\star *}}$ & $2002^{\star \star \star}$ & 2003 & 2004 \\
\hline Obrazy & 290 & 387 & 341 & 347 & 655 & 166 & 65 \\
\hline Rzeźby & 87 & 95 & 128 & 154 & 328 & $\cdot$ & $\cdot$ \\
\hline Zegary & 17 & 14 & 21 & 16 & 47 & 8 & 10 \\
\hline Kolekcje numizmatyczne & 1 (4,5tys. monet) & 4 & 2 & $\cdot$ & $\cdot$ & 1 (552 monety) & $\cdot$ \\
\hline Świeczniki, lichtarze & 55 & 44 & 88 & 52 & 58 & - & - \\
\hline Kielichy & 37 & 42 & 7 & 4 & 6 & - & - \\
\hline Ikony & 53 & $\cdot$ & $\cdot$ & 44 & 11 & - & - \\
\hline Starodruki & 70 & $\cdot$ & $\cdot$ & 6 & 70 & 50 & 2 \\
\hline Instrumenty muzyczne & $\cdot$ & $\cdot$ & $\cdot$ & 1 & - & - & - \\
\hline Porcelana & $\cdot$ & $\cdot$ & $\cdot$ & 40 & 82 & - & - \\
\hline Meble & $\cdot$ & $\cdot$ & 13 & ottarze & 30 & $\cdot$ & $\cdot$ \\
\hline Monstrancje & $\cdot$ & $\cdot$ & $\cdot$ & 2 & 3 & $\cdot$ & $\cdot$ \\
\hline
\end{tabular}

* Informacja dotycząca stanu zagrożenia przestępczością kryminalną skierowaną przeciwko dobrom kultury w 2000 r., „Cenne, Bezcenne, Utracone” 2001, nr 1, s. 12.

** Informacja nt. stanu zagrożenia przestępczością przeciwko dobrom kultury w Polsce w latach 1999-2001, „Cenne, Bezcenne, Utracone 2002, nr 1.

*** Informacja nt. stanu zagrożenia przestępczością przeciwko dobrom kultury w 2002 r., „Cenne, Bezcenne, Utracone" 2003, nr 1-2, s. 6-9.

Informacje KGP: Przestępczość przeciwko dobrom kultury, „Cenne, Bezcenne, Utracone” 2012, nr 1(70) s. 21-25.

Źródło: Obliczenia własne na podstawie danych kwartalnika „Cenne, Bezcenne, Utracone” z lat 1998-2004. 
$\mathrm{Z}$ danych zawartych w tabeli 3 widzimy, że najwięcej skradzionych dóbr kultury to: obrazy, rzeźby, monety, ikony, starodruki.

\section{Suma ubezpieczenia i metody jej określania}

Podstawowym parametrem przy ubezpieczeniu zabytków ruchomych jest określenie sumy ubezpieczenia. Oznacza to, że ubezpieczenie zabytków ruchomych powinno być dokonane na kwotę równą ich wartości rzeczywistej. Każda różnica między tymi wielkościami jest obustronnie niekorzystna, gdyż odszkodowania pokrywane są (wypłacane) do wysokości rzeczywistej szkody. Jak wiadomo, powstawanie nadubezpieczenia i niedoubezpieczenia ma swoje konsekwencje dla stron umowy ubezpieczenia. Również znaną zasadą jest, że odszkodowanie może być wypłacone $\mathrm{w}$ kwocie mniejszej lub równej sumie ubezpieczenia w zależności od wysokości szkody. Innymi słowy, suma ubezpieczenia zawarta w umowie ubezpieczenia jest górną granicą odpowiedzialności zakładu ubezpieczeń.

W wielu wypadkach ustalenie sumy ubezpieczenia obiektów zabytkowych ruchomych jest bardzo trudne. Wynika to ze specyfiki gromadzonych kolekcji, ich wysokiej wartości emocjonalnej, pamiątkowej, co utrudnia wycenę. W takich wypadkach negocjacje mogą doprowadzić jedynie do oszacowania sumy ubezpieczenia.

Sumę ubezpieczenia określa się z chwilą zawierania umowy ubezpieczenia. Brokerzy - agenci ubezpieczeniowi, zawierając umowę ubezpieczenia na zabytki ruchome muszą być wyposażeni w wiedzę o ich wartości oraz o warunkach zawarcia umowy, a także sposobach zabezpieczania. Oznacza to, że pośrednicy ubezpieczeniowi powinni przejść szkolenie z zakresu teorii i praktyki historii sztuki. Wiedza ta powinna być ciągle doskonalona, gdyż mamy do czynienia z ogromną różnorodnością ruchomych zabytków kultury. Należy przy tym przypomnieć, że pośrednicy nie są odpowiedzialni tylko za zawarcie umowy ubezpieczenia, ale także za jej wykonanie.

Analizując coroczne informacje dotyczące przestępczości w zakresie dóbr kultury widzimy, że zdecydowana większość to szkody do 100 tys. PLN. Zdarzają się jednak wypadki kradzieży dzieł o wysokiej wartości (tabela 4).

Przy przekroczeniu ustalonej granicy sumy ubezpieczenia decyzję o ubezpieczeniu zabytków ruchomych podejmować powinien zarząd zakładu ubezpieczeń.

Warunkiem poszukiwania sposobów określenia sumy ubezpieczenia dla zabytków ruchomych jest ich autentyczność (tzn., że nie są one falsyfikatami). Najłatwiejszym sposobem ustalenia sumy ubezpieczenia jest posiadanie rachunku (faktury) za zabytek ruchomy przez ubezpieczającego. Wiadomym powszechnie jest, że w miarę upływu 
czasu wartość zabytku ruchomego wzrasta. Stąd, posiadanie rachunku wystawionego z określoną datą ułatwia ustalenie sumy ubezpieczenia w okresie późniejszym. Wiadomo również, że zabytki ruchome (ich indywidualny niepowtarzalny charakter) nie stanowią przedmiotów ubezpieczanych masowo (jak np. samochody). Stąd zawieranie umów ubezpieczenia na określone zabytki ruchome powinno być poprzedzone profesjonalną dyskusją, wymianą poglądów, negocjacjami. W tym okresie powinny być szczegółowo omówione warunki zawarcia ubezpieczenia. Może wówczas pojawić się wartość wspólnie oszacowana (otaksowana), co może stanowić podstawę do ustalenia m.in. sumy ubezpieczenia. W tym momencie daje się zauważyć znaczny wpływ argumentów kolekcjonerów na treść warunków umowy. Jeśli zabytek ruchomy ujęty jest w zapisach księgowych jako środek trwały, wówczas ta wartość może być podstawą do ustalenia sumy ubezpieczenia.

Tabela 4. Szacunkowa wartość wybranych, skradzionych, ważnych ruchomych obiektów zabytkowych powyżej 5 mln PLN w Polsce i innych państwach

\begin{tabular}{|c|l|c|c|}
\hline Lp. & \multicolumn{1}{|c|}{ Określenie przedmiotu skradzionego } & Rok & $\begin{array}{c}\text { Szacunkowa } \\
\text { wartość }\end{array}$ \\
\hline 1 & Kradzież z zamku Sułkowskich w Rydzynie obrazu P. Patlera Pasterz krów & 1995 (sierpień) & 5,5 mln DM \\
\hline 2 & $\begin{array}{l}\text { Kradzież z Muzeum Sztuki Współczesnej w Paryżu pięciu obrazów, m.in. } \\
\text { Picassa, Matisse'a i Modiglianiego }\end{array}$ & $\begin{array}{c}2010 \\
(19 / 20 \text { maja) }\end{array}$ & $\begin{array}{c}\text { łączna wartość } \\
100 \text { mln EUR }\end{array}$ \\
\hline 3 & $\begin{array}{l}\text { Kradzież czterech obrazów Picassa z Galerii Sztuki Nowoczesnej w Pałacu } \\
\text { Sztembergów na Hradczanach (Czechy) }\end{array}$ & 2001 & 30 mln USD \\
\hline
\end{tabular}

Źródło: Informacja nt. stanu zagrożenia przestępczością przeciwko dobrom kultury w Polsce w latach 1999-2001, „Cenne, Bezcenne, Utracone” 2002, nr 1, s. 20; M. Marcinkowska, Cenne dzieła sztuki w łapach złodziei w Paryżu, „Cenne, Bezcenne, Utracone” 2010, nr 3, s. 24; P. Ogrodzki, Kradzieże dzieł sztuki i ich zwalczanie w Czechach, „Cenne, Bezcenne, Utracone” 2001, nr 6, s. 13.

Przy sprzedaży dzieł sztuki stosuje się wiele klauzul zabezpieczających ${ }^{9}$. Interesującą uwagę spotykamy przy stosowaniu przez zakład tzw. klauzuli mienia odzyskanego ${ }^{10}$. Zakłada się, że skradzione zabytki ruchome po upływie czasu mogą być odzyskane. Dla przykładu treść takiej klauzuli brzmi: „w przypadku odzyskania mienia, za które ubezpieczony otrzymał odszkodowanie na warunkach niniejszej umowy ubezpieczenia, ubezpieczonemu przysługiwać będzie prawo do jego odkupienia od ubezpieczyciela". W myśl tej klauzuli (kolekcjoner) właściciel zabytku może odzyskać skradzione dobra, za które wcześniej uzyskał stosowne odszkodowanie.

9 Zob. A. Grzywacz, Obrót dziełami sztuki, Lexis Nexis, Warszawa 2004.

10 Zob. I. Gredka, Ubezpieczenia dóbr kultury w zbiorach prywatnych, „Cenne, Bezcenne, Utracone” 2012, $\mathrm{nr} 2$, s. 36-37; I. Gredka, Klauzula mienia odzyskanego w umowie ubezpieczenia dóbr kultury, w: Rynek sztuki. Aspekty prawne, op.cit., s. 260-269. 
Zatem w wypadku szkody całkowitej ww. klauzula prowadzi wprost do wyzbycia się przez muzeum własności ubezpieczonych muzealiów. Przewiduje jednak, że w razie odzyskania utraconego mienia, za które ubezpieczony otrzymał odszkodowanie, ubezpieczonemu przysługuje prawo do odkupienia od ubezpieczyciela przedmiotu ubezpieczenia za cenę rynkową w ustalonym terminie (maksymalnie $60 \mathrm{dni}$ ).

Dla potrzeb określenia sumy ubezpieczenia ruchomych zabytków możemy wykorzystać opinię powołanych rzeczoznawców Ministra Kultury ${ }^{11}$. Rzeczoznawcy zostali ustanowieni na podstawie przepisu art. 141 ustawy z dnia 23 lipca 2003 r. o ochronie zabytków i opiece nad zabytkami (Dz. U. z 2004 r., nr 162, poz. 1568; Dz. U. z 2004 r., nr 96 poz. 959).

Do podstawowych obowiązków rzeczoznawców należy m.in. przygotowanie ocen i opinii w sposób obiektywny, według najlepszej wiedzy i z należytą starannością.

Pożądane umiejętności eksperckie rzeczoznawcy to ${ }^{12}$ :

- wszechstronna wiedza i doświadczenie,

- profesjonalne wykształcenie (np. architekt, inżynier),

- zamiłowanie do historii,

- wrażliwość na piękno, detale, stan techniczny,

- umiejętność odtworzenia realiów historycznych na podstawie pozostałości z dawnych czasów,

- świadomość specyficznych uwarunkowań powstania dzieł,

- znajomość wartości turystycznej dobra kultury.

Przy wykorzystaniu licencjonowanego rzeczoznawcy ustalającego sumę ubezpieczenia zabytku ruchomego należy się liczyć z kosztami tej wyceny. Każda wycena jest droga, gdyż przeciętnie wynosi ok. $3 \%$ wartości wycenianego zabytku (plus podatek) ${ }^{13}$. Może się zdarzyć, że podmiot zbywający zażąda kolejnej wyceny dokonanej przez innego rzeczoznawcę. Koszty te może pokryć kolekcjoner lub organizator ekspozycji.

Sumę ubezpieczenia dla wybranych zabytków ruchomych można ustalić, biorąc pod uwagę uzyskane wartości na aukcjach porównywalnych przedmiotów. Wartość zasugerowana na aukcji jest determinowana licznymi czynnikami, np. sytuacją ekonomiczną zbywcy, preferencjami zbywcy i nabywcy. Mimo wszystko stosowany wariant łączący kryterium wartości kulturowej i ekonomicznej na aukcji wydaje się najlepszą z możliwych podstawą wyceny zabytków ruchomych.

\footnotetext{
${ }^{11}$ P. Ogrodzki, Rzeczoznawcy Ministra Kultury powołani, „Cenne, Bezcenne, Utracone” 2005, nr 3, s. $18-19$.

12 A. Kiziniewicz, Ile sa te nasze zabytki warte - materialnie i niematerialnie?, „Nieruchomości” 2013, nr 5, s. 37-38; N. Fyderek, Eksperci rynku sztuki w Polsce - sytuacja prawna i praktyka, w: Rynek sztuki. Aspekty prawne, op.cit., s. 107-124.

${ }^{13}$ D. Flisak, Wywóz dóbr kultury za granicę, „Gazeta Antykwaryczna” 2008, nr 11, s. 7.
} 
Określenie wartości zabytku (dziedzictwa kulturowego) jako jego wartości ekonomicznej budzi wątpliwości. Przede wszystkim materialna wartość przedmiotu nie zawsze znajduje proste przełożenie na wartość kulturową, mimo że jest istotną przesłanką. Innym problemem jest rzetelność wyceny zabytków. Wiele dóbr kultury jest unikatem nieposiadającym odpowiedników, co wręcz uniemożliwia ustalenie ich realnej ceny.

Przy wycenach ruchomych obiektów zabytkowych należy wziąć pod uwagę fakt, że polskie prawo dość rygorystycznie traktuje wywóz zabytków na aukcje zachodnie. Praktycznie mamy do czynienia z zamkniętym rynkiem sztuki obiektów zabytkowych. Ten fakt ma swoje konsekwencje dla cen zabytków.

\section{Warunki ubezpieczenia ruchomych zabytków kultury}

Na początku lat 2000. próby ubezpieczenia ruchomych zabytków podejmowały takie zakłady jak: Hestia, PZU, Warta, firma brokerska „Protektor”. Przyjmowano różne poziomy stóp składek, liczne wyłączenia z zakresu odpowiedzialności ${ }^{14}$. W wielu wypadkach składka okazała się tak wysoka, że należało poszukiwać sponsorów do jej zapłacenia. Powyższe zakłady ubezpieczeń ubezpieczały prywatne kolekcje o wartości 0,5-1,0 mln PLN.

W latach 1990-1995 podstawą do zawierania umów ubezpieczenia obiektów sakralnych były umowy PZU podpisywane $\mathrm{z}$ diecezjami (w ramach porozumień z Episkopatem $)^{15}$. Taryfa składki od ognia wynosiła 1,5\%o. Dla mienia ruchomego przyjęto 2,5\%. Były to ubezpieczenia dobrowolne, także od kradzieży dzieł sztuki.

Przy zawieraniu umów ubezpieczenia na ubezpieczenie dóbr kultury konieczne są negocjacje ich treści. Wynika to $\mathrm{z}$ indywidualnego charakteru ubezpieczanego przedmiotu. Podstawą ułatwiającą zawarcie umów mogą i powinny być klauzule. Chodzi także o uniknięcie w warunkach umowy ubezpieczeniowej rażącej dysproporcji między ubezpieczającym a zakładem ubezpieczeń.

\footnotetext{
14 J.A. Likowski, Jak ubezpiecza się dzieła sztuki, „Cenne, Bezcenne, Utracone” 2001, nr 2, s. 20-21; M. Jaworski, Polisa na obraz, „Cenne, Bezcenne, Utracone” 2001, nr 3, s. 20-22.

$15 \mathrm{~J}$. Wiąckowski, B. Bogdański, Techniczne możliwości zabezpieczeń obiektów sakralnych $w$ Polsce, „Wiadomości Ubezpieczeniowe" 1995, nr 10, 11, 12, s. 8-9.
} 


\section{Zakres odpowiedzialności}

Zakład ubezpieczeń powinien ponosić odpowiedzialność za:

- uszkodzenie mechaniczne przedmiotu,

- kradzież w czasie ruchu zwiedzających,

- kradzież, gdy miejsce jest zamknięte dla zwiedzających,

- kradzież przez pracowników ubezpieczonego,

- szkodę powstałą w wyniku uszkodzenia opakowania,

- szkody spowodowane utlenianiem, klejem, oświetleniem, wahaniem temperatury, ciśnienia, wilgotności,

- szkody spowodowane przez gryzonie, owady.

Kradzież obiektu ruchomego zabytkowego ubezpieczonego i nieodnalezionego należy traktować jako szkodę całkowitą.

Bardzo ważnym elementem przy zawieraniu umów ubezpieczenia odgrywają sposoby zabezpieczenia dzieł sztuki przed kradzieżą. Ze względu na wartość tych dóbr zabezpieczenia przeciwkradzieżowe powinny być najwyższej klasy, a oprócz tego całodobowy monitoring wizyjny. Pożądana jest bezpośrednia łączność z policją lub firmami ochroniarskimi.

Równie ważna jest kalkulacja stopy składki w wypadku zabytków ruchomych. Aby policzyć stopę składki, potrzebne są szczegółowe dane o szkodach, ich liczbie i wypłaconych odszkodowaniach. Zagadnienie trudne, gdyż pokazane w artykule dane nie upoważniają do obliczenia prawdopodobieństwa (częstości) szkód. Brak parametru częstości szkód wynika z faktu, że zabytki ruchome mają indywidualny charakter, a także nie są masowe. W tym wypadku możemy się zwrócić np. do Policji, której baza danych mogłaby pomóc oszacować częstość szkód.

W lepszej sytuacji są zakłady ubezpieczeń, które „testowały” ubezpieczenie ruchomych zabytków jako produktu dodatkowego do innych rodzajów ubezpieczeń. Zdobyte doświadczenia mogą być przydatne do oszacowania częstości szkód. Patrząc od strony klientów, widzimy, że może się zdarzyć, iż ustalona stopa składki przekracza możliwości ekonomiczne ubezpieczającego. Ponadto dodatkowe warunki zabezpieczenia technicznego przeciwkradzieżowego, wysoki udział własny, mogą zniechęcić do ubezpieczenia np. posiadanych kolekcji. Stąd obie strony umowy powinny szukać rozwiązań, idąc na kompromis.

Jak dotychczas zakłady ubezpieczeń, obejmując ochroną ubezpieczeniową zabytki ruchome, traktują ją jako coś dodatkowego do innych umów ubezpieczenia. Stąd nie tworzą jednolitych OWU, lecz zawierają umowy ubezpieczenia na warunkach indywidualnych (szczególnych). Są to dobrowolne ubezpieczenia majątkowe.

Ubezpieczenie muzealiów najczęściej jest związane z ubezpieczycielem krajowym. 
W ramach UE obowiązuje dyrektywa o zwrocie skradzionych dóbr kultury, a także współpracy między państwami członkowskimi w celu ograniczenia zjawiska ${ }^{16}$.

Klauzule from wall to wall czy from nail to nail wyznaczają początek i koniec ochrony ubezpieczeniowej.

Ubezpieczenie ruchomych dóbr kultury wypożyczonych na określony czas dotyczyć może wystaw krajowych i zagranicznych.

$\mathrm{W}$ wypadku wystaw czasowych ważne jest określenie przedmiotu ubezpieczenia. Mogą to być rzeczy ruchome znajdujące się w muzeach, zwane muzealiami. W myśl art. 21 ust. 1 i ust. 1a (Dz. U. 1997, nr 5, poz. 24 z późn. zm.) muzealiami „są rzeczy ruchome i nieruchomości stanowiące własność muzeum i wpisane do inwentarza, który utworzyło muzeum. Muzealia stanowią dobra narodowe". Umowy ubezpieczenia są zawierane przy każdorazowym ich wypożyczeniu.

Podejmując się ubezpieczenia ruchomych zabytków, należy posiadać w zakładzie ubezpieczeń kwalifikowaną osobę do likwidacji szkód. Osoba ta powinna posiadać nie tylko wiedze teoretyczną, ale i wieloletnie doświadczenie praktyczne, np. w muzeach, przy organizacji galerii, wystawa ekspozycyjnych. Nie bez znaczenia jest posiadana praktyka zdobyta w obszarze ochrony i poszukiwania skradzionych zabytków ruchomych.

Ponieważ wiele ruchomych zabytków kultury ma bardzo dużą wartość rynkową, koniecznością jest przewidzenie reasekuracji tych przedmiotów ubezpieczenia.

\section{Podsumowanie}

Z przeprowadzonych rozważań widzimy, że pole ubezpieczeniowe (liczba zabytków kultury) jest w Polsce dość duże. To, co udało się ocalić po II wojnie światowej i ochronić przed kradzieżą czy wywozem za granicę, należy chronić wszelkimi dostępnymi środkami. Jednym z nich jest właśnie ubezpieczenie zabytków kultury, dzieł sztuki od kradzieży. Z artykułu możemy wyciągnąć następujące wnioski:

1. Zakłady ubezpieczeń majątkowo-osobowych muszą wystąpić z bardziej konkretną ofertą ubezpieczenia ruchomych zabytków kultury w Polsce.

2. Konieczne jest wypracowanie pewnych standardów w zakresie wyceny ruchomych zabytków kultury.

16 W. Paczulski, Zwalczanie nielegalnego handlu dobrami kultury w Unii Europejskiej, „Cenne, Bezcenne, Utracone” 2006, nr 1, s. 34-36; W. Paczulski, Wspólpraca administracyjna państw członkowskich przy licencjonowaniu wywozu dóbr kultury z Unii Europejskiej, „Cenne, Bezcenne, Utracone” 2005, nr 4, s. 43-44. 
3. Zabytki kultury powinny być objęte obowiązkowymi ubezpieczeniami.

Podjęta problematyka nie została wyczerpana, lecz jedynie zasygnalizowana. Konieczne są dalsze opracowania.

\section{Bibliografia}

Bowring J., Ubezpieczenie dzieł sztuki - uwagi ogólne, w: Rynek sztuki. Aspekty prawne, red. W. Kowalski, K. Zalasińska, Wolters Kluwer Polska, Warszawa 2011.

Flisak D., Wywóz dóbr kultury za granicę, „Gazeta Antykwaryczna” 2008, nr 11, s. 7.

Fyderek N., Eksperci rynku sztuki w Polsce - sytuacja prawna i praktyka, w: Rynek sztuki. Aspekty prawne, red. W. Kowalski, K. Zalasińska, Wolters Kluwer Polska, Warszawa 2011.

Geppert E., Z zagadnień ubezpieczeń dzieł sztuki, „Wiadomości Ubezpieczeniowe” 1975, nr 11.

Gredka I., Klauzula mienia odzyskanego w umowie ubezpieczenia dóbr kultury, w: Rynek sztuki. Aspekty prawne, red. W. Kowalski, K. Zalasińska, Wolters Kluwer Polska, Warszawa 2011.

Gredka I., Ubezpieczenia dóbr kultury w zbiorach prywatnych, „Cenne, Bezcenne, Utracone" 2012, nr 2.

Grzywacz A., Obrót dziełami sztuki, Lexis Nexis, Warszawa 2004.

Informacja dotycząca stanu zagrożenia przestępczością kryminalna skierowana przeciwko dobrom kultury w 2000 r., „Cenne, Bezcenne, Utracone” 2001, nr 1.

Informacja na temat zagrożenia przestępczościa przeciwko dobrom kultury w Polsce w 2009 r., „Cenne, Bezcenne, Utracone” 2010, nr 1.

Informacja nt. skali zagrożenia przestępczościa kryminalna przeciwko zabytkom w latach 2004-2005, „Cenne, Bezcenne, Utracone” 2006, nr 1.

Informacja nt. skali zagrożenia przestępczością kryminalna przeciwko zabytkom w Polsce w latach 2005-2006, „Cenne, Bezcenne, Utracone” 2007, nr 1.

Informacja nt. stanu zagrożenia przestępczościa przeciwko dobrom kultury w Polsce w latach 1999-2001, „Cenne, Bezcenne, Utracone” 2002, nr 1.

Informacja nt. stanu zagrożenia przestępczością przeciwko dobrom kultury w 2002 r., „Cenne, Bezcenne, Utracone" 2003, nr 1-2.

Informacja nt. stanu zagrożenia przestępczościa przeciwko dobrom kultury w Polsce w latach 1999-2001, „Cenne, Bezcenne, Utracone” 2002, nr 1.

Informacje KGP: Przestępczość przeciwko dobrom kultury, „Cenne, Bezcenne, Utracone” 2012, nr 1(70).

Jaworski M., Polisa na obraz, „Cenne, Bezcenne, Utracone” 2001, nr 3. 
Kiziniewicz A., Ile sa te nasze zabytki warte - materialnie i niematerialnie?, „Nieruchomości" 2013, nr 5.

Korzeniowska-Marciniak M., Gdzie szukać skradzionych dziel sztuki, „Gazeta Antykwaryczna" 2002, nr 6.

Krochmal A., Ochrona polskiego dziedzictwa narodowego poza granicami kraju, „Cenne, Bezcenne, Utracone" 2006, nr 1.

Leszczyński M., Ochrona zabytków sztuki sakralnej w świetle aktualnego prawa Kościoła katolickiego, „Muzealnictwo” 2008, nr 49.

Likowski J.A., Jak ubezpiecza się dzieła sztuki, „Cenne, Bezcenne, Utracone” 2001, nr 2.

Marcinkowska M., Cenne dzieła sztuki w łapach złodziei w Paryżu, „Cenne, Bezcenne, Utracone" 2010, nr 3.

Ogrodzki P., Kradzieże dziet sztuki i ich zwalczanie w Czechach, „Cenne, Bezcenne, Utracone" 2001, nr 6.

Ogrodzki P., Przestępczość przeciwko zabytkom. Krótka charakterystyka problemu. Stan na rok 2010, „Cenne, Bezcenne, Utracone”, Ośrodek Ochrony Zbiorów Publicznych, Warszawa 2010.

Ogrodzki P., Rzeczoznawcy Ministra Kultury powołani, „Cenne, Bezcenne, Utracone” 2005, nr 3.

Paczulski W., Wspólpraca administracyjna państw członkowskich przy licencjonowaniu wywozu dóbr kultury z Unii Europejskiej, „Cenne, Bezcenne, Utracone” 2005, nr 4.

Paczulski W., Zwalczanie nielegalnego handlu dobrami kultury w Unii Europejskiej, „Cenne, Bezcenne, Utracone" 2006, nr 1.

Wiąckowski J., Bogdański B., Techniczne możliwości zabezpieczeń obiektów sakralnych w Polsce, „Wiadomości Ubezpieczeniowe” 1995, nr 10, 11, 12.

Ustawa z 27 czerwca 1997 r. o bibliotekach, Dz. U. 1997, nr 85, poz. 539 r. z późn. zm.

Ustawa z 21 listopada 1996 r. o muzeach, Dz. U. 1997, nr 5, poz. 24 z późn. zm.

Ustawa z 23 lipca 2003 r. o ochronie zabytków i opiece nad zabytkami, Dz. U. 2003, nr 162, poz. $1568 \mathrm{z}$ późn. $\mathrm{zm}$.

Rozporządzenie Ministra Kultury z 19 kwietnia 2004 r. w sprawie wywozu zabytków i przedmiotów o cechach zabytków za granicę, Dz. U. 2004, nr 84, poz. 789 z późn. zm.

\section{Insurance Against Theft of Movable Cultural Property in Poland}

Insurance coverage is one of the methods of providing security for movable cultural property. The article discusses the scale of theft of such objects in Poland and methods of valuation for the purposes of determining the sum of insurance. 
Keywords: movable cultural monuments, property insurance

\section{L'assurance contre le vol des biens culturels mobiliers de l'exposition permanente en Pologne}

En Pologne, il y a beaucoup de monuments culturels mobiliers. Nous devons protéger ce patrimoine culturel en utilisant tous les moyens disponibles. Dans la période 2000-2010, de nombreux vols sont devenus un fléau. Dans cet article, nous montrons la possibilité de leur protection par l'assurance contre le vol. Nous discutons l'ampleur du phénomène du vol des biens culturels mobiliers ainsi que les méthodes d'évaluation des biens afin de déterminer la somme de l'assurance.

Mots-clés: les biens culturels mobiliers, l'assurance des biens

\section{Страхование от кражи движимых культурных ценностей в Польше}

Страхование является одним из способов обеспечения безопасности движимых культурных ценностей. В статье рассматриваются масштабы воровства этих объектов в Польше и методы определения их страховой стоимости.

Ключевые слова: движимые культурные ценности, страхование имущества 